\title{
Effect of Anatomical Structure of Shoots in Different Flowering Phase on Rhizogenesis of Once-blooming Roses
}

\author{
Marta J. MONDER ${ }^{1}$, Paweł KOZAKIEWICZ ${ }^{2 *}$, Agnieszka JANKOWSKA ${ }^{2}$ \\ ${ }^{1}$ Polish Academy of Science Botanical Garden - Center for Biological Diversity Conservation in Powsin, Department of Botanical \\ and Garden Collection, Prawdziwka 2,02-973Warsaw,Poland; mondermarta@obpan.pl \\ ${ }^{2}$ Warsaw University of Life Science WULS-SGGW, Department of Wood Science and Wood Preservation, Nowoursynowska 166, 02-787 \\ Warsaw,Poland;pawel_kozakiewicz@sggw.pl( (*orrespondingauthor);agnieszka_jankowska@sggw.pl
}

\begin{abstract}
The research was conducted on five once-blooming different origin historical roses. The aims were establishing differences in the anatomical structure of shoots taken in four maturity stages and their natural ability to roots creating. There were hypothesized, that the changes in anatomical structure occur in the time of flowering and may affect the ability of rhizogenesis. Single node one leaf cuttings of chosen cultivars were cut from shoots in four maturity phases: flower buds closed, all flowers open, just after and 7-14 days after petal fall. The cuttings were planted in multipot trays in peat substrate without using rooting stimulators. The anatomical structure of shoots in the place of rhizogenesis were observed, the width of xylem layer and cambial zone, diameter of vascular cells were measured. The percentage of rooted cuttings and forming only a callus were counted. Adventitious roots appeared probably in the cambium zone, pith rays, and also in the zone of phloem and pericycle. The anatomic structure of shoots changes during the period of flowering and influences rooting percentage and the percent of cuttings which developed callus only. The width of the cambium layer of shoots influences the width of the wood layer in all cultivars. The rise of width of cambium tissue have an effect of increase of percentage of cuttings forming a callus only in 'Hurdals' and 'Maiden's Blush'. The width of the cambium layer in shoots enlarges during full blooming in four of the studied cultivars ('Hurdals', 'Maiden's Blush', 'Mousseuse Rouge', 'Semiplena') and in one it stays at the same level for the whole duration of the experiment ('Duchesse d'Angoulême'). The specifying in practice the period of taking rose cuttings, individual properties of cultivars and phenological phase of shoot should be taken into consideration.
\end{abstract}

Keywords: anatomical structure, callus, cuttings, maturity of shoots, old roses, phenology, rhizogenesis, stock plants

\section{Introduction}

The many of old cultivars can be successfully cultivated in harsher temperate zone conditions and are highly decorative (Quest-Ritson and Quest-Ritson, 2003). The high vitality and frost resistance of historical roses indicate on possibility their cultivation on own roots and economically favourable methods of propagation by stem cuttings. However, the cuttings of historical roses rooted in long period of time (Moroz 2006; Monder at al., 2014; Monder et al., 2016), whereas the efficiency of rooting and quality of a cutting is an integral production factor (Blythe et al. 2007). In nursery practice, the cuttings are cut from flowering shots in various terms without differentiation of phenology phase. The single-bud cuttings of species like Rosa canina (Hoşafçi et al., 2005) or Rosa $\times$ dumalis Bechst.
(Ercişli et al., 2005) and numerous cultivars of historical roses root in a lower extent and quality (Moroz 2006; Ginova et al., 2012).

In the stems cut off from the mother plants occur a series of processes e.g. gene expression, metabolic and anatomical changes connected with wound response. It was reported, that the internal structure of the stem cuttings had a determining role in adventitious rooting of most vascular plants (Dams et al., 1990). In research on five ground cover rose cultivars was showed, that the time and place of rhizogenesis varied (Pietrakowski, 2006). The first tissue in wounded place of shoots is a callus, that with the cooperation of various growth factors may be differentiate into the roots (Kolasiński, 2006). Moreover, the anatomical structure of the shoot within rhizogenesis can be affected by various substances, e.g. synthetic stimulants in rhododendrons (Strzelecka, 2007), carbon dioxide (Costa $e t$ al., 2007) and IBA, NAA in roses (Pietrakowski, 2006). 
During the vegetative season one of the most important processes is the lignification of wood cell walls after the end of growth, which allows, among other things, proper transportation of water. Developing a flower by the shoot means the termination of growth of the shoot from the apical bud. It was hypothesized, that the changes in anatomical structure occur in the time of flowering and may affect the ability of rhizogenesis. The research aimed at establishing differences in the anatomical structure of shoots in fallowing phenological phases of flowering shoots taken for cuttings, to highlight the influence of lignification of tissues on rooting capacity. Also, the goal was to It was also to determine where rhizogenesis occurred in cuttings taken in four stages of shoot maturity. The application meaning is designation the possibilities of effective propagation of difficult-to-root roses according to phenological phase.

The EU Council Directives recommend using less chemicals in plant production and applying integrated methods of cultivation and protection (OJEU a, b). The use of natural predisposition of plants, in this case for the onceblooming roses the selection the shoots characterized favourable and possibly appropriate anatomically structure in different maturity phase, can be recognized as environmentally friendly method. The short period of flowering is typically for once-blooming roses including many historical cultivars (Monder, 2007, 2012, 2014).

\section{Materials and Methods}

The shoots of roses were cut off from shrubs growing in the National Collection of Rose Cultivars in Polish Academy of Sciences Botanical Garden CBDC in Powsin, in four maturity phases: A - flower buds closed; B - all flowers in an inflorescence open; C - just after petal fall; D - 7-14 days after petal fall. The single node stem cuttings were rooted without preparations supporting rhizogenesis, in multipot trays $(6.6 \times 6.6 \mathrm{~cm})$ in peat substrate, in the commercial nursery of M. M. Kryt in Wola Prażmowska $\left(51.56^{\circ} \mathrm{N}, 20.28^{\circ} \mathrm{E}\right)$, in standard conditions in a foil tunnel $\left(23-25^{\circ} \mathrm{C}\right.$, ambient relative humidity $\left.80-90 \%\right)$. There were chosen once-blooming highly valued historical roses harvested in days:

-'Duchesse d'Angoulême' (France, bred by Vibert, 1821, Gallica): A - 31 May, B - 9 June, C - 17 June, D - 29 June;

-'Hurdals' (Germany-Norway; origin unknown, $R$. xalba $\mathrm{x}$ R. villosa): A - 27 May, B - 1 June, C - 6 June, D - 11 June;

-'Maiden's Blush' (origin unknown; described before 1400, cultivated before 1629, Alba): A - 1 June, B - 9 June, C - 17 June, D - 28 June;

$-R$. helenae 'Semiplena' (V. Petersen, Denmark; seedling of $R$. helenae) (Gustavsson, 1999); A - 29 May, B - 8 June, C 19 June, D - 2 July;

-'Mousseuse Rouge' (France; origin unknown, before 1842; Moss Rose) (Rosenverzeichnis, 1988): A - 7 June, B - 12 June, C - 20 June, D - 1 July.

After 10 weeks, percentage of rooted cuttings and cuttings which only developed callus was counted.

\section{Anatomical research}

For anatomical research, fragments of shoots were sampled at each stage of shoot maturity in the period when cuttings were taken (in June), in the course of rooting (on 25 day) and separately after 10 week. The cuttings were stabilized in a solution of ethyl alcohol and glycerine (v:v 1:1). Microscopic examinations were carried out in the Department Wood Science and Wood Protection, Warsaw University of Life Sciences (WULS), Warsaw, Poland. Slides were prepared with cross- and longitudinal sections from basal parts of shoots (place where rhizogenesis occurs). The 10-20 slides were obtained from one shoot (research variant) in order to seek ones that would best illustrate the rhizogenesis process and which would also be representative. The width of xylem layer and cambial zone, diameter of vascular cells were measured of each of four maturity stages of shoots before and on 25 day of rooting. The sledge microtome was used to cut samples in slices of 10-30 $\mu \mathrm{m}$ thickness each. Due to varied hardness of individual tissues and cells, the process of sectioning was hindered. Slides were cross-dyed with a solution of safranine and observed in the passing light with an Olympus BX41 (Olympus America Inc., New York, USA) microscope with a digital camera Olympus DP25 attachment linked to a computer with specialists software Cell ${ }^{*} \mathrm{~B}$ with possibility of measurement of the anatomical structure elements. Macroanatomical photos were taken in the PAS BG CBDC in Powsin.

\section{Statistical analysis}

In this experiment 20 cuttings in 4 repeats were planted for each phase maturity of shoots, in total 320 . The 1600 cuttings were assessed for five cultivars together. The experiment were randomized block system for cultivar. The width of xylem layer and cambial zone, diameter of vascular cells were measured in 10 samples taken from each of four maturity stages of shoots before and after 25 days of rooting. The all collected data were subjected to analysis of variance with the ANOVA procedure using STATISTICA 10 software (Statsoft Poland, Kraków, Poland). In order to evaluate significance of differences between the means, the Duncan's tests were used at a $p=0.05$ level of significance. Percentages of cuttings were initially transformed by the Bliss function (Wójcik and Laudański, 1989) and with the Tukey's test analyzed. The correlation between percentage of rooted cuttings and cuttings with callus only, xylem and cambial zone, wood cells diameter before rooting were calculated.

\section{Results}

The anatomy of stem in fallowing phenological phases before and after rooting

Based on the sections taken from shoots in four stages of maturity, it was stated that one-year rose shoots have a typical anatomical structure for species with lignifying plants (Figs. 1 and 2). In this experiment, the callus tissue began to appear near the base of rooting cuttings around day 14 from placing them in the substrate, and the first visible roots appeared around week 4 (Fig. 3).

\section{Anatomy of mother plant stems}

Vascular bundles on all cross-sections were well outlined, whereby the shoots with closed buds were outlined less even and with wider and more clearly visible pith rays. The core pith in shoots taken from cuttings consists of big loosely spread isodiametric cells (Figs. 1 and 2). 
410

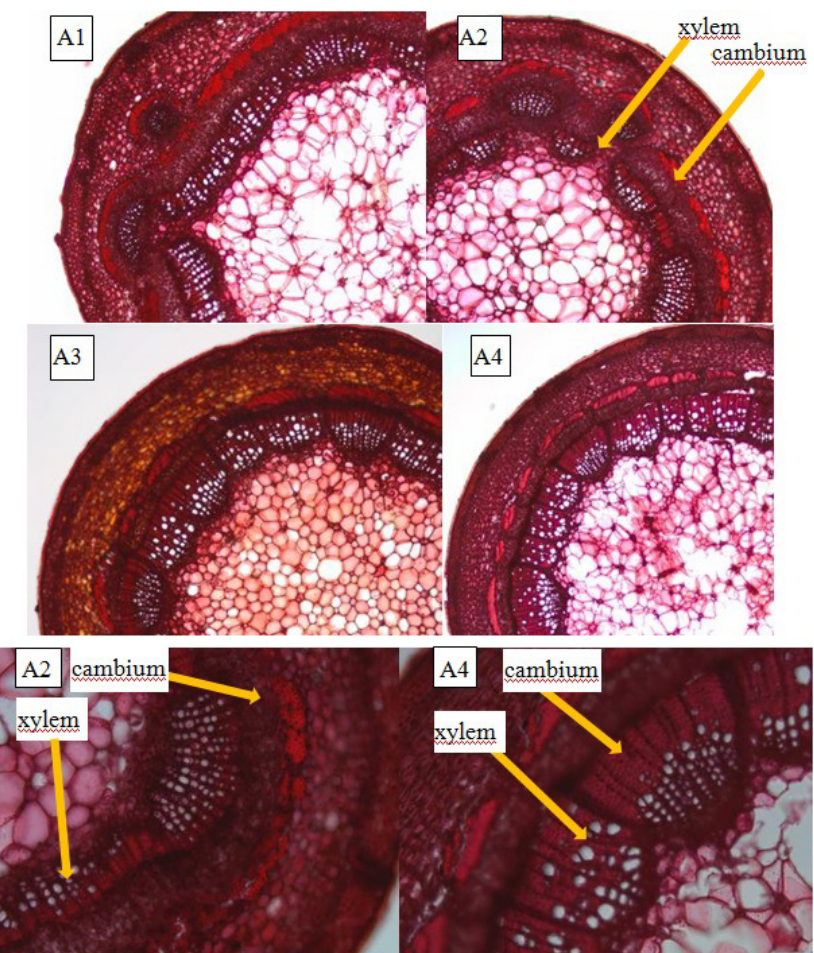

Fig. 1. Examples of the shoots section before rooting of Rosa 'Hurdals' in phenological phases: A1 - flower bud closed; A2 opened flower; A3 - just after petal fall;A4 - 7-14 days after falling petal
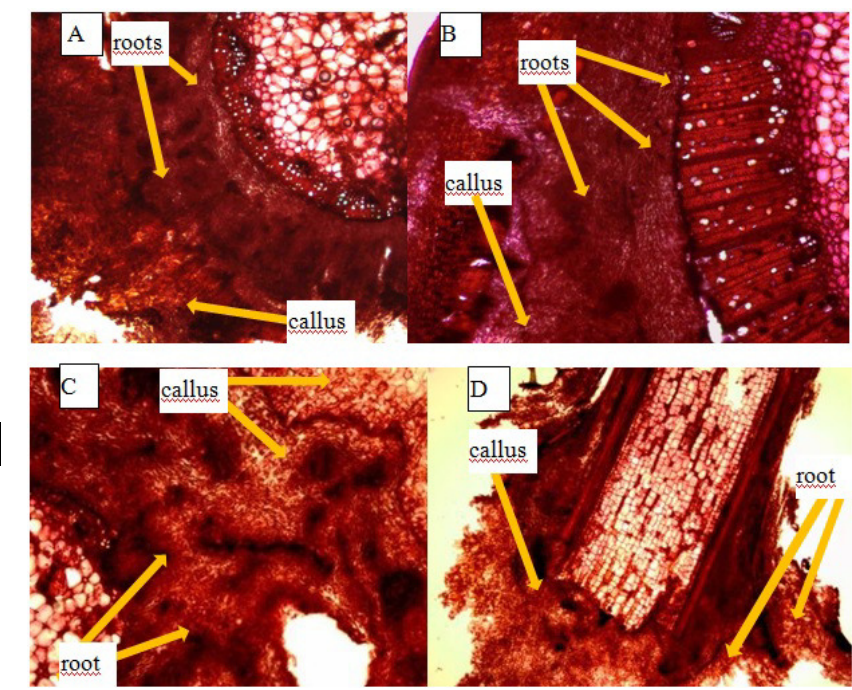

Fig. 3. Examples of the shoots section 25 days after rooting of: A - Rosa 'Duchesse d'Angoulême' cuttings from shoots with flower bud closed; B - Rosa 'Semiplena' cuttings from shoots with opened flower; C - Rosa 'Mousseuse Rouge' cuttings from shoots just after petal fall; D - Rosa 'Mousseuse Rouge' 7 14 after falling petals

\section{Adventitious root formation in stem cuttings}

The rhizogenesis is carried out analogically for all cultivars of four phenological phases. Root formation began by differentiating groups of parenchyma cells, initiating the rhizogenesis process. Adventitious roots originated probably
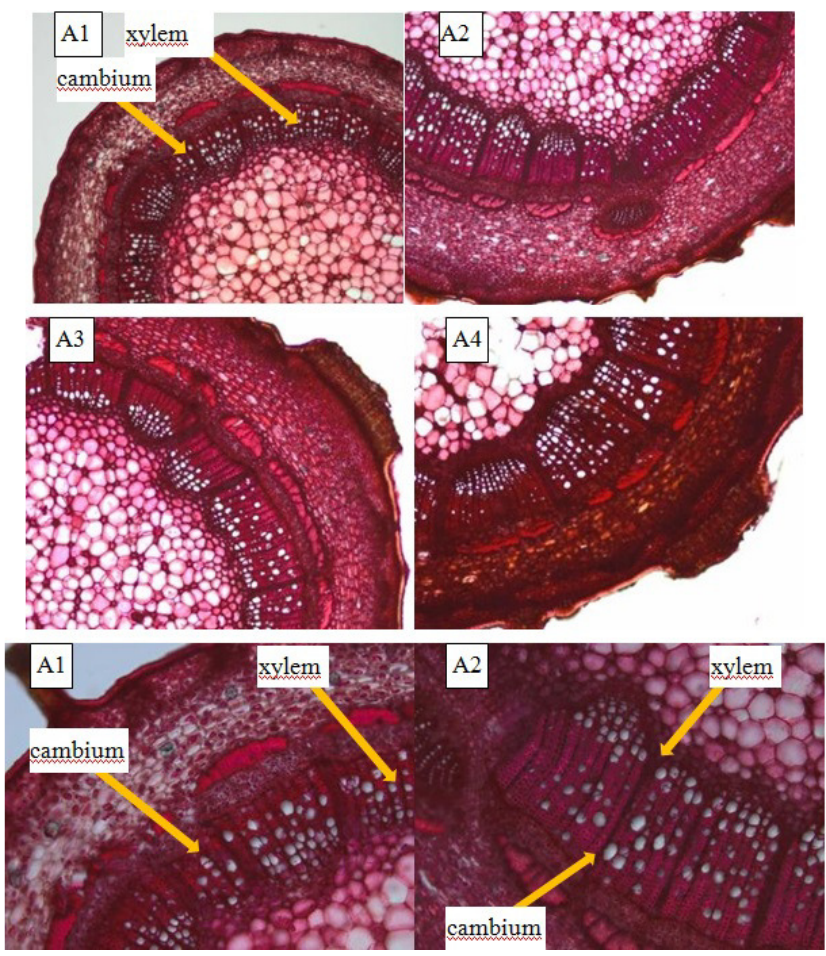

Fig. 2. Examples of the shoots section before rooting of Rosa 'Mousseuse Rouge' in phenological phases: A1 - flower bud closed; A2 - opened flower; A3 - just after petal fall; A4 - 7 14 days after falling petal

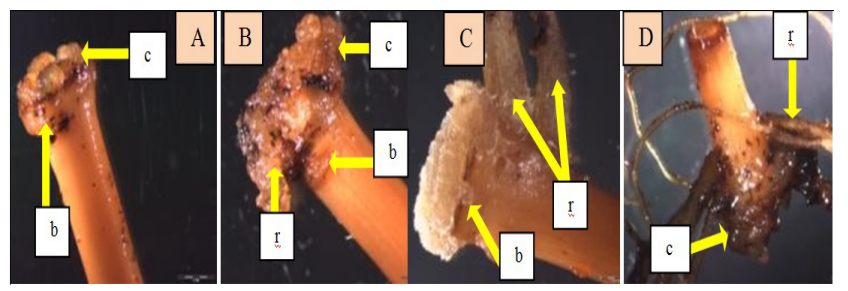

Fig. 4. The basis of Rosa 'Duchesse d'Angoulême' cuttings25 days after placing in substrate (A-C) and after 10 weeks (D): A - formation of callus; B - overgrowing callus lumpy structure; $\mathrm{C}$ - forming of roots; $\mathrm{D}=-$ the basal part of cutting after 12 weeks. Designations: c - callus; b - cuttingsdistensionbase, leading to burstof tissues; $r$ - adventitious roots

in the cambium zone, often in the place of extending pith rays. The root primordia were formed, and then root apical meristems covered with a cap. The forming shoots stretch tissues of phloem and sclerenchyma, then cortex and periderm. The rooted cutting after 10 weeks at the section have a very regular structure, similar to shoots of associated mother plants, but where the uniform annual ring is already visible.

There were observed macroanatomical differences in rhizogenesis. It was noticed that they perhaps also appear in the zone of phloem and pericycle (Fig. 3), which occurred more often when roots were created later along the shoot, skipping the basal part with the strongly expanded callus. This is characteristic for 'Duchesse d'Angoulême' (Fig. 4) and 'Mousseuse Rouge'. 'Maidens'a Blush' and 'Hurdals' created the roots on the base only and has a high tendency 
to create a callus. 'Semiplena' don't have a tendency to create a callus and the roots grew on the base, along the stem and in the vicinity of cuttings node.

\section{The tissues}

The width of cambium zone of 'Duchesse d'Angoulême' before rooting were undifferentiated on following phases maturity of shoots and lower. The layer of cambium increased after 25 days in A, B, D and were the highest in cuttings derived from shoots with all flowers open (Fig. 5). Before rooting the wood cells diameter remained on similar level in phases A, B, C, a width of xylem tissue were higher in shoots B i C comparing with $\mathrm{A}$ and $\mathrm{D}$. After 25 days a width of xylem tissue and diameter of cells decreased in shoots all phases (Figs. 6 and 7).

The width of cambium zone of 'Hurdals' cuttings before rooting were the highest in shoots with flowers open, and the lowest in shoots A and C. After 25 days width of cambium zone increased in shoots of all phases (Fig. 5). In shoots of cuttings before rooting width of xylem tissue of $B$ was the highest, but wood cells diameter had similar level in all phases. After 25 days width of xylem tissue increased only in $\mathrm{A}$ and decreased in $\mathrm{C}$ and D. The wood cells diameter increased for A, B and D, but the level persisted similarly in shoots $C$ (Figs. 6 and 7 ).

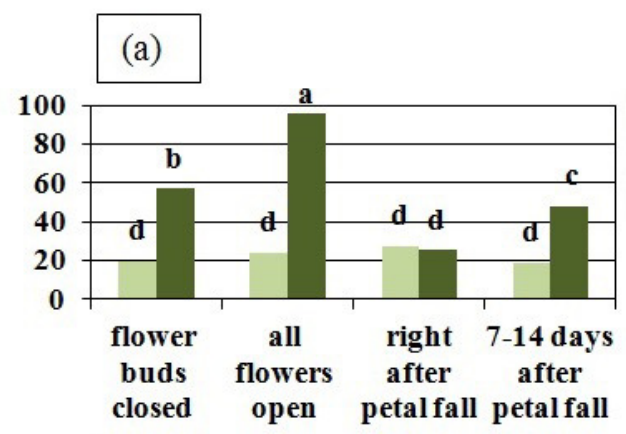

(c)

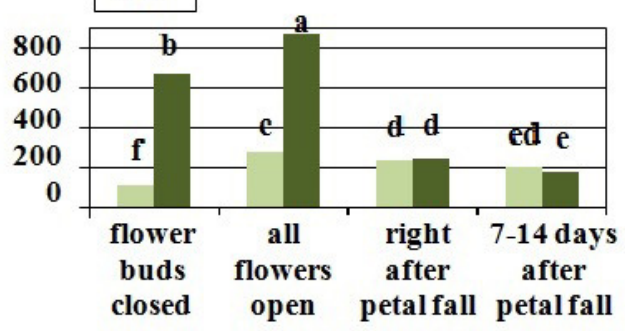

(e)

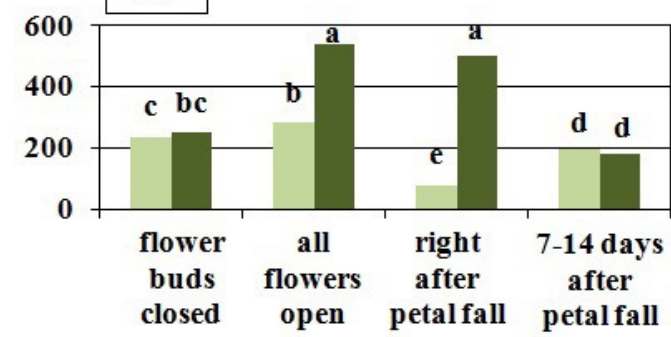

After preparation of the cuttings of 'Maiden's Blush' the width of cambium zone were the highest in shoots with B and the lowest in shoots with A. The width of cambium increased in shoots A and B and remained at similar level in C, 25 days later (Fig. 5). The width of xylem tissue in shoots of mother plants was the highest in shoots with flower buds closed in comparison to $\mathrm{B}, \mathrm{C}, \mathrm{D}$, where were similar. The width of this tissue remained at similar level after 25 days in A shoots, and increased for shoots of B, C, D (Fig. 6). The highest wood cells diameter was in shoots with opened flowers before rooting. The results for this parameter increased in A, B, D shoots, and decreased for C (Fig. 7).

In the shoots of mother plant 'Mousseuse Rouge' before rooting, the width of cambium zone were the highest in shoots C, and the lowest in shoots with A. The width of cambium increased after 25 days for cuttings derived from shoots A, B and D and remained on the same highest level in $\mathrm{C}$ shoots (Fig. 5). The width of xylem tissue of before rooting shoots were similar. After 25 days the width of xylem tissue were higher than before in shoots $\mathrm{A}$ and lower in $\mathrm{B}$ and $\mathrm{C}$ (Fig. 6). The wood cell diameter were the highest in shoots of mother plants cut with flower buds closed. After 25 days diameter decreased for cuttings of shoots of all maturity phases (Fig. 7).

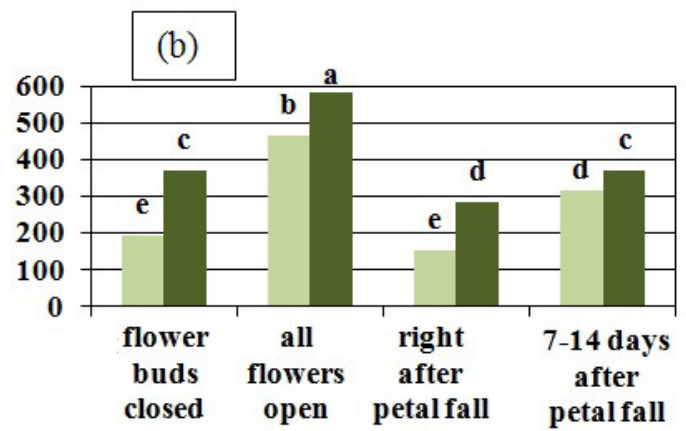

(d)

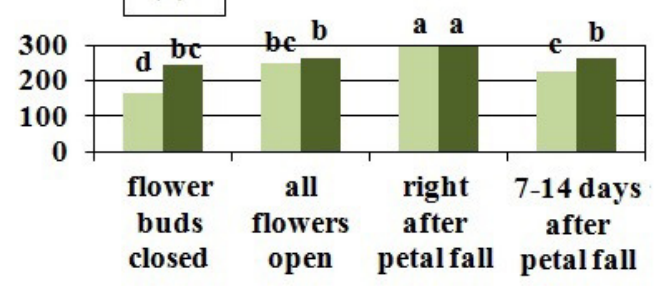

before rooting after rooting

Fig. 5. The means of width of cambium tissue $(\mu \mathrm{m})$ in the zone of root formation at the moment of shoots cutting and 25 days after in rooting period for cuttings from shoots of four maturity phases. Designation: a - 'Duchesse d'Angoulême', b - 'Hurdals', c - 'Maiden's Blush', d - 'Mousseuse Rouge', e - 'Semiplena'. Note: different letters indicate significant differences, according to Duncan's test (two-way ANOVA) 

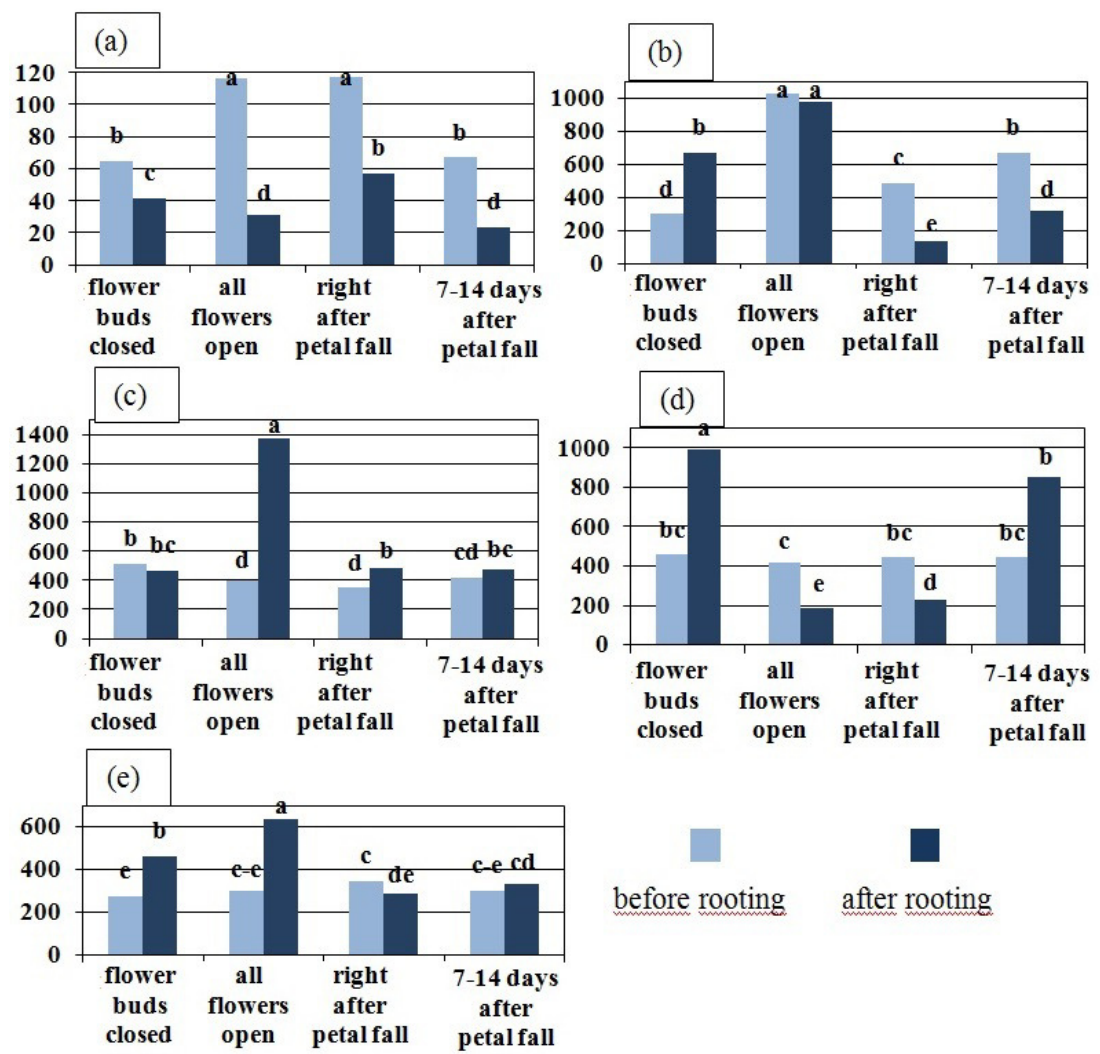

before rooting after rooting

Fig. 6. The means of width of xylem tissue $(\mu \mathrm{m})$ in the zone of root formation at the moment of shoots cutting and 25 days after in rooting period for cuttings from shoots of four maturity phases. Designation: a - 'Duchesse d'Angoulême', b - 'Hurdals', c 'Maiden's Blush', d - 'Mousseuse Rouge', e - 'Semiplena'. Note: different letters indicate significant differences, according to Duncan's test (two-way ANOVA).
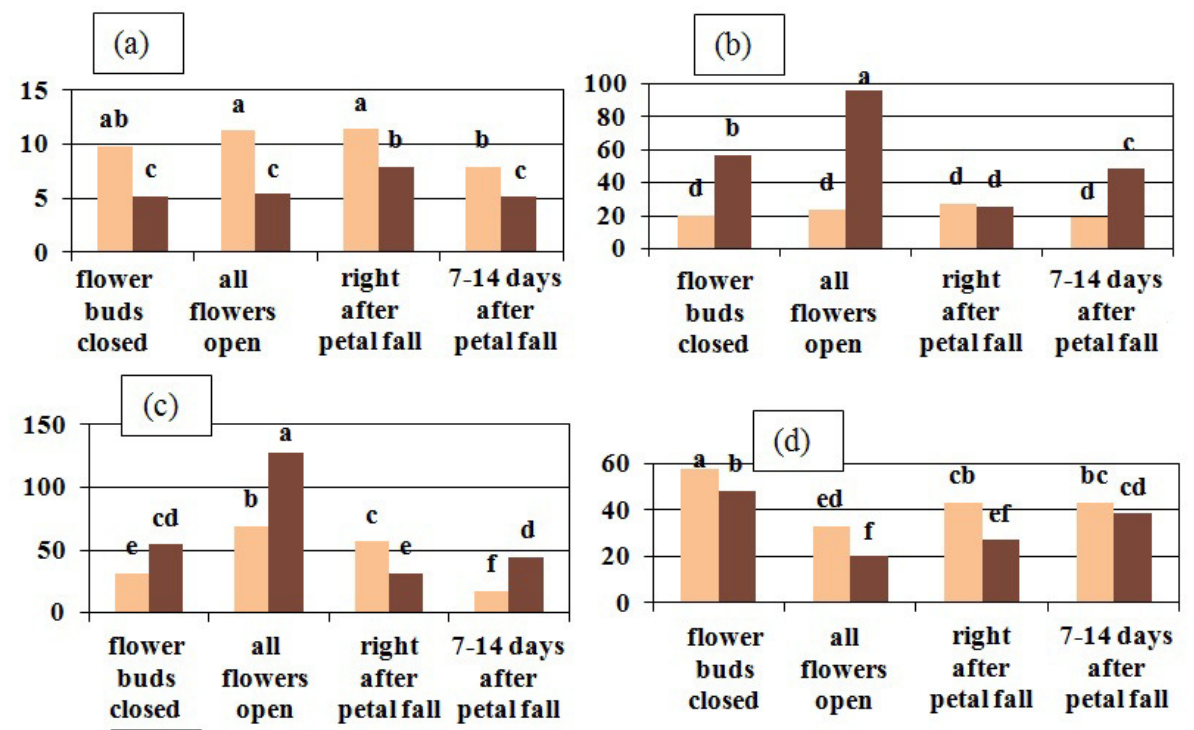

(e)

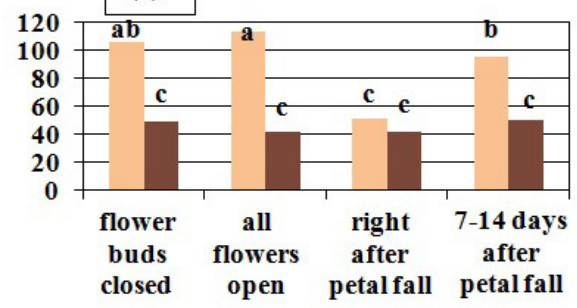

before rooting after rooting

Fig. 7. The means of wood cells diameter $(\mu \mathrm{m})$ in the zone of root formation at the moment of shoots cutting and 25 days after in rooting period for cuttings from shoots of four maturity phases. Designation: a - 'Duchesse d'Angoulême', b - 'Hurdals', c 'Maiden's Blush', d - 'Mousseuse Rouge', e - 'Semiplena'. Note: different letters indicate significant differences, according to Duncan's test (two-way ANOVA) 


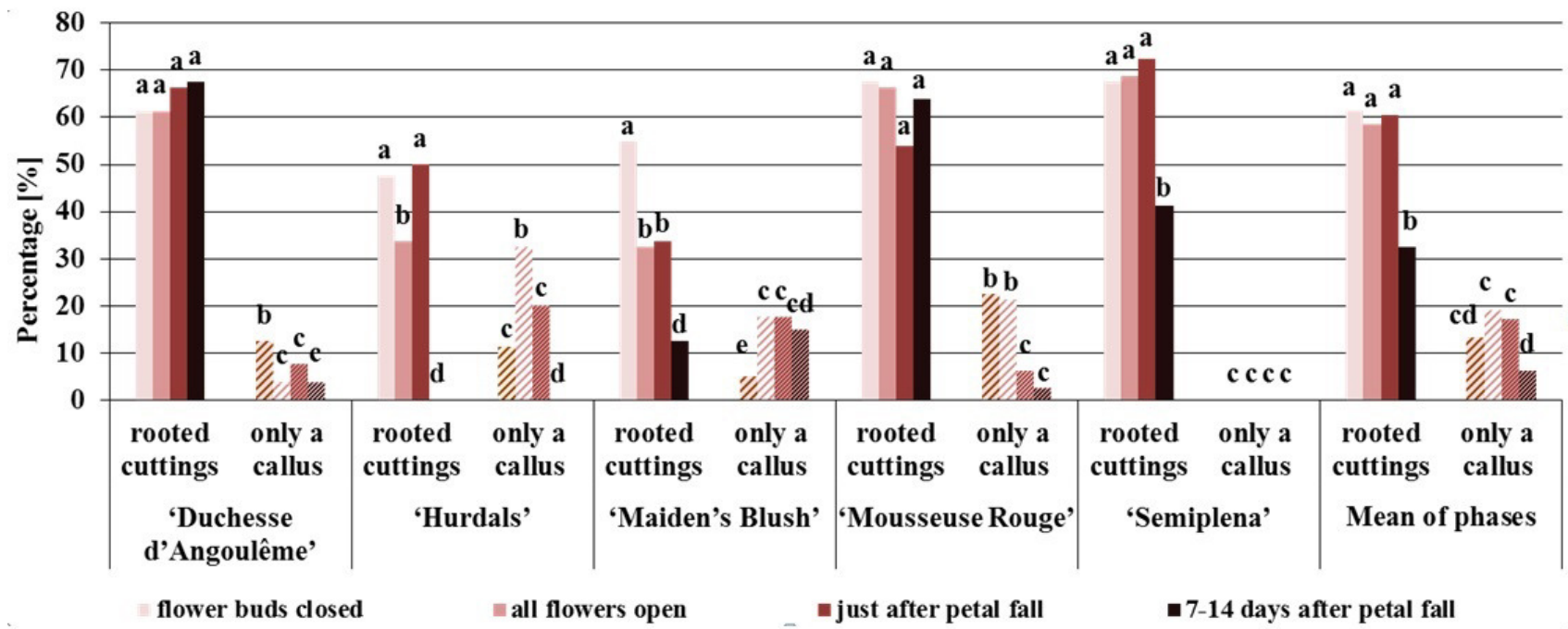

Fig. 8. The percentage of rooted cuttings and cuttings forming only a callus. Note: different letters indicate significant differences in each cultivars separately and in each phases for all cultivars, according to Duncan's test (two-way ANOVA). The means of phase contains general means for all the cultivars, separately for each phase

The width of cambium zone of 'Semiplena' shoots were the highest in shoots B and the lowest in shoots C. After 25 days in cuttings derived from shoots $\mathrm{B}, \mathrm{C}$ the width of this tissue grew up and A, D remained on the similar level (Fig. 5). The width of xylem remained on similar level in all maturity of shoots before rooting. After 25 days the width of this tissue increased in cuttings derived from shoots $\mathrm{A}$ and B, but decreased for cuttings from shoots $\mathrm{C}$ (Fig. 6). Before rooting the wood cells diameter were the highest in shoots of A and B phases. This diameter decreased 25 days later and were similar for cuttings derived from shoots of all maturity phases (Fig. 7).
The rhizogenesis according to the width of xylem layer and cambial zone, diameter of vascular cells before rooting

The results of rooting percentage and the percentage of cuttings with callus only are showed on Fig. 8. The cuttings of 'Duchesse d'Angoulême' and 'Mousseuse Rouge' of all maturity phases shoots rooted in similar percentage within the cultivar data. However, the highest percentage of cuttings of 'Duchesse d'Angoulême' with only a callus were noticed for shoots with flowers bud closed and for 'Mousseuse Rouge' were observed for A and B comparing with B and D. The cuttings of 'Maiden's Blush' and 'Semiplena' derived from shoots 7-14 days after petal fall

Table 1. Effects correlation matrices between rooting percentage and anatomical structure of shoots before rooting

\begin{tabular}{|c|c|c|c|c|c|c|}
\hline Cultivar & Variable & $\begin{array}{c}\text { Wood cells } \\
\text { diameter }[\mu \mathrm{m}]\end{array}$ & $\begin{array}{c}\text { Width of xylem } \\
{[\mu \mathrm{m}]}\end{array}$ & $\begin{array}{c}\text { Width of } \\
\text { cambium }[\mu \mathrm{m}]\end{array}$ & $\begin{array}{c}\text { Rooted cuttings } \\
{[\%]}\end{array}$ & $\begin{array}{l}\text { Cuttings with } \\
\text { callus only [\%] }\end{array}$ \\
\hline \multirow{5}{*}{ 'Duchesse d'Angoulême' } & Wood cells diameter $[\mu \mathrm{m}]$ & 1.000 & & & & \\
\hline & Width of xylem $[\mu \mathrm{m}]$ & $0.568^{*}$ & 1.000 & & & \\
\hline & Width of cambium $[\mu \mathrm{m}]$ & $0.484^{*}$ & $0.865^{*}$ & 1.000 & & \\
\hline & Rooted cuttings [\%] & 0.156 & $0.381^{*}$ & 0.253 & 1.000 & \\
\hline & Cuttings with callus only [\%] & -0.005 & 0.072 & 0.046 & -0.143 & 1.000 \\
\hline \multirow{6}{*}{ 'Hurdals' } & Wood cells diameter $[\mu \mathrm{m}]$ & 1.000 & & & & \\
\hline & Width of xylem $[\mu \mathrm{m}]$ & 0.141 & 1.000 & & & \\
\hline & Width of cambium $[\mu \mathrm{m}]$ & -0.076 & $0.762^{*}$ & 1.000 & & \\
\hline & Rooted cuttings [\%] & $-0.166^{*}$ & 0.038 & 0.077 & 1.000 & \\
\hline & Cuttings with callus only [\%] & -0.114 & $0.370^{*}$ & $0.237^{*}$ & $0.307^{*}$ & 1.000 \\
\hline & Wood cells diameter $[\mu \mathrm{m}]$ & 1.000 & & & & \\
\hline \multirow{4}{*}{ 'Maiden's Blush' } & Width of xylem $[\mu \mathrm{m}]$ & $-0.344^{*}$ & 1.000 & & & \\
\hline & Width of cambium $[\mu \mathrm{m}]$ & $0.577^{*}$ & $-0.530^{*}$ & 1.000 & & \\
\hline & Rooted cuttings [\%] & $0.484^{*}$ & 0.119 & -0.056 & 1.000 & \\
\hline & Cuttings with callus only [\%] & 0.072 & $-0.294^{*}$ & $0.323^{*}$ & $-0.417^{*}$ & 1.000 \\
\hline \multirow{5}{*}{ 'Mousseuse Rouge' } & Wood cells diameter $[\mu \mathrm{m}]$ & 1.000 & & & & \\
\hline & Width of xylem [ $\mu \mathrm{m}]$ & 0.149 & 1.000 & & & \\
\hline & Width of cambium $[\mu \mathrm{m}]$ & $-0.311^{*}$ & $-0.169^{*}$ & 1.000 & & \\
\hline & Rooted cuttings [\%] & $0.297^{*}$ & 0.131 & $-0.337^{*}$ & 1.000 & \\
\hline & Cuttings with callus only [\%] & $-0.301^{*}$ & -0.136 & -0.030 & $-0.650^{*}$ & 1.000 \\
\hline \multirow{5}{*}{ 'Semiplena' } & Wood cells diameter $[\mu \mathrm{m}]$ & 1.000 & & & & \\
\hline & Width of xylem [ $\mu \mathrm{m}]$ & $-0.558^{*}$ & 1.000 & & & \\
\hline & Width of cambium $[\mu \mathrm{m}]$ & $0.668^{*}$ & $0.504^{*}$ & 1.000 & & \\
\hline & Rooted cuttings [\%] & -0.050 & 0.029 & 0.020 & 1.000 & \\
\hline & Cuttings with callus only [\%] & - & - & - & - & 1.000 \\
\hline
\end{tabular}

Note: Marked correlations are significant at $\mathrm{p}<0.05 .{ }^{*}$ Correlation significance: $0.161-0.289$ - low restrained; 0.290-0.499 - restrained; 0.500-0.699 - high; $>0.700$ - very highly. 
414

have a lowest percentage, but in the case of the 'Hurdals' did not root at all and decayed. The $32.5 \%$ cuttings of 'Hurdals' derived from shoots B were forming only a callus and it was the highest result. The percentage cuttings with callus only of 'Maiden's Blush' were similar for B, C, D and higher than for A. The shoots of 'Semiplena' didn't form the cuttings with only a callus (Fig. 8).

It was observed that the strong development of the callus limited the origination of the root system near the base of the shoot. The some examples were showed on Fig. 4. It was noticed that after 12 weeks some of the cuttings ('Duchesse d'Angoulême', 'Semiplena'), also the ones with the excessive callus, created roots along the section of the internode near the base or over the base with callus ('Mousseuse Rouge'). The cultivars with the lack of ability to rhizogenesis in the internode area of cuttings rooted in lower percentage ('Maiden's Blush', 'Hurdals').

Analysis of correlations for the rooted cuttings showed that a higher rooting percentage were correlated with a higher diameter of wood cells in 'Maiden's Blush' and 'Mousseuse Rouge' and lower in 'Hurdals'. Moreover, the higher rooting percentage of 'Mousseuse Rouge' was related to a lower width of cambium zone. The higher percentage with callus only were correlated with increasing width of cambium and xylem layer of 'Hurdals' and in the case of 'Maiden's Blush' with the increasing of width of cambium and decreasing of xylem tissues (Table 1).

The analysis shown that the increasing of width of cambium is correlated with increasing of width xylem tissue for 'Duchesse d'Angoulême', 'Hurdals', 'Semiplena' and decreasing this parameter for 'Maiden's Blush' and 'Mousseuse Rouge'. The width of cambium tissue is correlated with the wood cells diameter. The increasing of width of this tissue were correlated with increasing of wood cells diameter for 'Duchesse d'Angoulême', 'Maiden's Blush', 'Semiplena' and with the decreasing for 'Mousseuse Rouge'. Moreover, the higher percentage of cuttings only with callus correlated with the increasing width of cambial and xylem zone in 'Hurdals', increasing of width of cambium layer and decreasing of xylem zone in 'Maiden's Blush'. The decreasing percentage of cuttings only with callus of 'Mousseuse Rouge' correlated with increasing wood cells diameter (Table 1).

\section{Discussion}

The following study shows diversification of the anatomic structure of shoots, both in the studied rose cultivars and in consecutive phenological phases during flowering according to specified parameters. So far, morphological and anatomical diversification of cultivars has been shown by studies conducted on pillar roses (Delinschi et al., 2009a, b). Moreover, in various phases of development of shoots during flowering, changes were shown in the content of chlorophyll $a$ and $b$, carotenoids, proteins and carbohydrates, which affected the rooting of historical roses (Monder et al., 2016).

Seasonal changes in the content of biologically active components (carbohydrates) in plants and the influence of these changes on rhizogenesis were also the subject of studies on many different species, e.g. Olea europaea L. (Del Rio, 1991; Denaxa et al., 2012) and may be recognized as natural and connected with the life cycle of plants.

Adventitious roots formation in cuttings of trees and shrubs appeared in the cambium zone (Kolasiński, 2006), in the place of extending pith rays. Haissig (1974) claims that adventitious roots can also be created within phloem and in pericycle. Researchers are inclined to claim that the cambium zone is the main tissue where primordia of adventitious roots appear. In researches of Fouda and Schmidt (1994), Pietrakowski (2006), Costa et al. (2007) on roses was not found which tissues of new parenchyma belong to phloem, xylem and cambium. In many plant species, roots of cuttings are rarely formed from the callus especially in difficult-to-root species and cultivars (Czekalski, 1983) and they may be located in nodes, internodes and lenticels (Kolasiński, 2006). In studies made by Costa $e t$ al. (2007), proliferation of the new parenchyma tissue (callus), probably due to cambial meristematic activity, precedes adventitious root formation in cuttings of Rosa Madelon'. Roots initiated within the new formed parenchyma tissue, close to the secondary xylem, which is in line with previous findings by Fouda and Schmidt (1994), who reported for Rosa rugosa Thunb. that adventitious roots originated from the callus tissue at the basal cut surface of the stem.

In some species, the callus intensively expands, using up most nutrients and inhibiting the development of roots. In ones which root easily, the development of the callus is usually weaker (Buraczyk and Zakrzewski, 1990). In this research, the all cultivars of roses formed roots in the basal part of cutting. The problem is the origination of a large callus on the base where the cutting was taken, and that the cutting dies back after some time. The strong development of the callus limited the origination of the root system near the base of the shoot. However, the roses that creating the roots along the stem, rooted in higher percentage. In the case of cultivars in which a higher percentage of cuttings with callus only was noted, and in which roots in these cuttings did not develop along the shoot, low rooting percentage ('Hurdals', 'Maiden's Blush') was shown. 'Semiplena', in which cuttings developing only callus were not noted and in which roots developed along the stem and in the node area as well, had a higher rooting percentage. A tendency to create well-developed callus depends also on the phenological phase of the shoots taken for cuttings. Younger tissues $(\mathrm{A}, \mathrm{B}, \mathrm{C})$ had a stronger tendency to create the callus tissue. The cuttings of $D$ of 'Hurdals' did not root and those of 'Maiden's Blush' had a lower rooting percentage. The reason for that may also be the fastadvancing process of aging (Monder $e t$ al., 2016) e.g. in 'Hurdals'. Changes were shown in the content of biologically active components (proteins, chlorophyll $a$ and $b$, carotenoids, polyphenolic acids) in consecutive phenological phases of shoots and the influence of the changes on rhizogenesis of once-blooming historical roses suggests a diversification in the pace of this process in the studied rose cultivars (Monder et al., 2016).

The conducted measurements of width of cambium, xylem zone and xylem cells diameter indicated on differentiation between cultivars and in following phenological phases. The width of cambium tissue of 'Duchesse d'Angoulême' in mother plants is on the same level in all phenological phases. In other cultivars the width 
of this layer grows until full blooming ('Hurdals', Maiden's Blush', 'Semiplena') or even until just after blooming ('Mousseuse Rouge'), which suggests big activity of cambium cell divisions during the development of flowers. For all cultivars the width of the cambium layer is connected with the width of the xylem tissue, which is related to the plant's big demand for water during full development of the flower. However, the bigger activity of cambium cells probably contributes during rhizogenesis to an excessive development of the callus tissue in B ('Hurdals', 'Maiden's Blush') and decrease rooting percentage in this phase in relation to $\mathrm{A}$. For $\mathrm{C}$ cuttings the tendency continues. During the process of rhizogenesis the cambium layer in all cultivars increases its width in relation to the original state at the moment of taking the cutting, which may be also connected with the development of cells of other tissues.

The largest width of the xylem layer tissue were in B of 'Hurdals', 'Maiden's Blush' and 'Semiplena'. That is connected probably with high activity of cambium tissue. Moreover, the wood tissue layer have a tendency to decrease its participation in stem. It may be connected with a changing of width diameter of rooting shoot. Then, the mean width of xylem cells in the first 25 days of rhizogenesis (connected with new smaller diameter wood cells) has decreased in 'Duchesse d'Angoulême' and 'Mousseuse Rouge', that did not proved influence phenological stage of shoots on rooting percentage of cuttings, and 'Semiplena', which had a high rooting percentage for $\mathrm{A}, \mathrm{B}$ and $\mathrm{C}$.

\section{Conclusions}

The anatomic structure of shoots changes during the period of flowering and influences the percent of rooted cuttings, as well as the percent of cuttings which developed callus only. The percentage of the rooted cuttings and the tendency to create callus only were different in five cultivars. Strong development of callus limited the inception of the root system near the base of the shoot. Cuttings of cultivars which developed roots not only in their basal part but also along the shoots and in the node area, rooted in a higher percentage. Cuttings which created only callus do not have practical importance and are undesirable.

Adventitious roots appeared after 25 days, probably in the cambium zone, in the place of extending pith rays, and also in the zone of phloem and pericycle. The width of the cambium layer in cross-sections of shoots influences the width of the wood layer and increasing of cuttings with callus only in a varied way depending on the cultivar. The width of the cambium layer in shoots enlarges during full blooming in four of the studied cultivars ('Hurdals', 'Maiden's Blush', 'Semiplena') and in one ('Duchesse d'Angoulême') it stays at the same level for the whole duration of the experiment.

The research carried out on the above mentioned historical roses confirms that when specifying in practice the period of taking rose cuttings, individual properties of cultivars as well as the phenological phase and the related level of shoot maturity should be taken into consideration.

\section{Acknowledgements}

The studies were financed by National Science Centre 2011-2014 [the research project no. NN 310008240].

\section{References}

Blythe EK, SibleyJL, Ken M, Tilt KM, RuterJM (2007). Methods of auxin application in cutting propagation: a review of 70 years of scientific discovery and commercial practice. Journal of Environmental Horticulture 25(3):166-185.

Buraczyk W, ZakrzewskiJ (1990). Fizjologiczne aspekty procesu rizogenezy w pędach drzew i krzewów [Physiological aspects of rhizogenesis process in shoots of trees and shrubs]. Wiadomości Botaniczne 34:3-12.

Czekalski M (1983). Korzenie przybyszowe i ich powstawanie [Secondary roots and their formation]. KosmosSA Biologia 1:91-99.

Costa JM, Heuvelink E, Pol PA, Put HMC (2007). Anatomy and morphology of rooting in leafy rose stem cuttings and starch dynamics following severance. Acta Horticulturae 751:495-502.

Dams HA, Thompson S, Pirre A (1990). Vegetative propagation of Acacia mangium by stem cuttings, the effect of seedling age and phyllode number on rooting Journal of Tropical Science, Forest Research Institute, Malaysia 2(4):224279.

Delinschi V, Stănescu I, Mihalache M, Adumitresei L (2009)a. Morphoanatomical considerations upon the shoot of some Rosa $\mathrm{L}$. cultivars from the botanic garden of Iasi (1st note).Journal of Plant Development 16:9-16.

Delinschi V, Stănescu I, Mihalache M, Adumitresei L (2009)b. Morphoanatomical considerations upon the shoot of some Ros $\mathrm{L}$ cultivars from the botanic garden of Iasi (2st note). Analele științifice ale Universității "Al. I. Cuza" Iaşi, Biologie Vegetală Tomul LV, fasc 2, sII a:47-54.

Del Rio C, Rallo L, CaballeroJM (1991). Effects of carbohydrate content on the seasonal rooting of vegetative and reproductive cuttings of olive. Journal of Horticultural Science 66:301-309.

Denaxa NK, Vemmos SN, Roussos PA (2012). The role of endogenous carbohydrates and seasonal variation in rooting ability of cuttings of an easy and a hard to root olive cultivars (Olea europaea L). Scientia Horticulturae 143:19-28.

ErcişliS, Eşitken A, Anapali O, Şahin U (2005). Effects of substrate and IBAconcentration on adventitious root formation on hardwood cuttings of Rosa dumalis. Acta Horticulturae 751:149-152.

Fouda RA, Schmidt G (1994). Histological changes in the stems of some Rosa species propagated by leafy cuttings as affected by IBA treatments. Acta Agronomica Hungarica 43:265-275.

Ginova A, Tsvetkov I, Kondakova V (2012). Rosa damascena Mill - an overview for evaluation of propagation methods. Bulgarian Journal of Agricultural Science 18(4):514556.

Gustavsson L-Å (1999). Rosenlexikon. Rosinante Forlag A/S. Kopenhaga.

Haissig BE (1974). Origins of adventitious roots. New Zealand Journal of Forestry Sciences 4(2):299-310.

Hoşaçi H, Arslan N, Sarihan EO (2005). Propagation of dog rose (Rosa canina L.) plants by softwood cuttings. Acta Horticulturae 690:139142

Kolasiński M (2006). The effect of incision wounding of cuttings and of a rhizogenesis promoter on the rooting of dawn redwood (Metasequoia glyptostroboides Hu et Cheng). European Journal of Polish Agricultural Universities 9(1):01. 
416

Monder MJ (2007). Zasoby genowe i ocena wybranych odmian róż historycznych w kolekcji Ogrodu Botanicznego CZRB PAN [Genetic resources and evaluation of selected historical roses]. Zeszyty Problemowe Postępów Nauk Rolniczych 517(II):487-494.

Monder MJ (2012). Evaluation of growth and flowering of cultivars derived from the Rugosa (Rosa mgosa Thunb.) growing in the National Collection of Rose Cultivars in the Polish Academy of Sciences Botanical Garden in Powsin. Part I. The historical cultivars. Acta Agrobotanica 65(2):109-116.

Monder MJ (2014). Evaluation of growth and flowering of historical cultivars of Rosa gallica L. growing in the National Collection of Rose Cultivars in the Polish Academy of Science Botanical Garden in Powsin. Acta Agrobotanica 67(3):39-52.

Monder MJ, Niedzielski M, Woliński K (2014). Effect of rooting preparations on protein, chlorophyll and carotenoid content in leaves of Rosa gallica 'Duchesse d'Angoulême' cuttings. Dendrobiology 72:2940.

Monder MJ, Niedzielski M, Woliński K, Pacholczak A (2016). The impact of seasonal changes in plant tissue on rhizogenesis of stem cuttings of the once flowering roses. Notulae Botanicae Horti Agrobotanici ClujNapoca 44(1):92-99.

Moroz EK (2006). Korniesoobstwiennyje rozy w Nacionalnom Parkie 'Sofiewka', [Roses on own roots in National Park 'Sofiewka']. NANU Centralnyj BotaniczeskijSad, Umań.
OJEU (2009a). Official Journal of the European Union 2009. Directive 2009/128/EC of the European Parliament and of the Council of 21 October 2009 establishing a framework for Community action to achieve the sustainable use of pesticides. L309/71-86.

OJEU (2009b). Official Journal of the European Union 2009. Regulation (EC) No 1107/2009 of the European Parliament and of the Council of 21 October 2009 concerning the placing of plant protection products on the market and repealing Council Directives 79/117/EEC and 91/414/EEC.L309/1-50.

Pietrakowski D (2006). Wpływ dolistnego stosowania auksyn na ukorzenianie sadzonek róż z grupy okrywowych [Effect of foliar application of auxin on the rooting of rose cuttings from the ground cover group]. PhD thesis, Poznań University of Life Sciences, Poznań, Poland.

Rosenverzeichnis Rosarium Sangerhausen (1988). 3 Auflage, Sangerhausen, Germany.

Quest-Ritson C, Quest-Ritson B (2003). The Royal Horticultural Society Encyclopaedia of Roses. London, England: Penguin Company.

Strzelecka K (2007). Anatomical structure and adventitious root formation Rhododendrom ponticum L. cuttings. Acta Scientiarum Polonorum Hortorum Cultus 6(2):15-22.

Wójcik AR, Laudański Z (1989). Planowanie i wnioskowanie statystyczne $\mathrm{w}$ doświadczalnictwie [Planning and statistical inference in experiments].PWN, Warsaw, Poland. 